\title{
Plasticulture: Diffusion of Plastic Materials in the Agricultural Sector
}

\author{
VALENTINA CONSTANȚA TUDOR, DRAGOȘ ION SMEDESCU*, GINA FÎNTÎNERU, ALEXANDRU FÎNTÎNERU, \\ ALINA MARCUTA, RADU ANDREI IOVA \\ University of Agronomic Sciences and Veterinary Medicine of Bucharest, 59 Marasti Blvd,011464, Bucharest, Romania
}

For more than half a century, the use of plastic in agriculture has given farmers opportunities for growing fruits and vegetables regardless of the season, and at the same time achieving better quality compared to open-field cultivation. The use of plastics, through various specific techniques, helps reduce the consumption of various resources such as water, energy, fertilizers or pesticides. We could say that without these plastics a significant amount of cultivated fruits and vegetables could not be harvested in early conditions and could not be preserved and conditioned in controlled parameters. Plastic is a very important material for economy but also in everyday life. The use of plastic in agriculture has increased from year to year, thus contributing to both the increase of agricultural production and the improvement of the quality of food.Plastics are a wide range of synthetic or semi-synthetic materials that are used for various purposes. In the plastic industry, are used raw materials, such as cellulose, coal, natural gas, salt and, of course, crude oil. Plastics are extremely versatile materials and are ideal for a wide range of applications for industry as well as for consumers.

Keywords: plastic use, agriculture, plastic, improvement, production, white pollution

The term "plastic" derives from the Greek word "plastikos", which means it is suitable for modeling. This refers to material malleability or plasticity during manufacture, which allows it to be molded, pressed or extruded into a variety of shapes such as foil, fiber, plates, tubes, bottles, cans and many more [20].

The use of plastic has grown in agriculture since the 1950s [7] when agronomists have discovered that using polyethylene film controls and moderates soil temperature, [12] prevents its drying and at the same time limits the growth of weeds, all of which contribute to higher production at lower costs [6].

Plastics began to be used for the first time in America in 1948 when farmers opted for cellophane greenhouses, and Japanese began to use PVC. [15] Since then, the use of these types of plastics has become more and more common in many countries, making it a much cheaper and more practical alternative to glass used to cover greenhouses or paper and straws used for mulching [14].

At the same time, this discovery has played and plays a very important role in the economy, [17] because, with the growth of the population, the need for food has grown too, [8] thus creating a real plastics industry. For example, the use of the mulch foil registered an increase of $69 \%$ in 2019 compared to 2012 [16].

However, as good things do not last forever, the intensive use of polyethylene in agriculture damages the soil, releasing toxins that can last for hundreds of years [18] and at the same time release carcinogenic phthalate acid esters which are absorbed into the soil, presenting a considerable risk to human health.

The remaining polyethylene residues on the ground create the phenomenon called white pollution [10].

Plasticulture, representing the use of plastic materials in agriculture, is present in the form of agricultural ponds, greenhouses, solariums, tunnels, micro-irrigation installations such as drip irrigation and sprinklers, plastic mulching film and plastic crates.

\section{Experimental part}

Designed and used from its origins in agriculture as an accelerator and amplifier of natural effects on plant growth, plasticulture fulfills a biomimetic perspective, doubling and improving what exists in nature [19].

In many countries, many crops are no longer grown without the use of plastics, some crops being no longer produced in the open field, only to be produced in greenhouses and solariums. Considering that in some regions of the world, nothing can be cultivated without the use of plastic, [1] if producers could no longer use plastic, it is estimated that the production of fruit and vegetables would fall by about $75 \%$.

A wide range of plastics are used in agriculture including polyolefin, polyethene (PE), Polypropylene (PP), EthyleneVinyl Acetate Copolymer (EVA), Poly-vinyl chloride (PVC) and less frequently, Polycarbonate (PC) and poly-methylmethacrylate (PMMA) [11]. 


\section{Results and discussions}

In order to be more competitive on the current market, fruit and vegetable producers are always looking for solutions to obtain first, high quality and secondly earlier production [13] than would produce in a traditional system.

Plasticulture, combining the use of raised beds, plastic mulch, drip irrigation and fumigation, has led to the achievement of the above mentioned targets by more and more producers. Plastics are used in agriculture for the following: (Tab. 1)

Table 1

USE OF PLASTIC MATERIALS IN AGRICULTURE

\begin{tabular}{|c|c|c|}
\hline PROTECTED CULTIVATION FILMS & $\begin{array}{l}\bullet \\
\bullet \\
\bullet \\
\bullet \\
\bullet \\
-\end{array}$ & $\begin{array}{l}\text { Greenhouse and tunnel } \\
\text { Low tunnel } \\
\text { Mulching } \\
\text { Nursery films } \\
\text { Direct covering } \\
\text { Covering vineyards and orchards }\end{array}$ \\
\hline NETS & $\begin{array}{l}\bullet \\
\bullet \\
\bullet \\
\bullet \\
\bullet\end{array}$ & $\begin{array}{l}\text { Anti-hail } \\
\text { Anti-bird } \\
\text { Wind breaking } \\
\text { Shading } \\
\text { Nets for olives and nut picking }\end{array}$ \\
\hline PACKAGING & $\begin{array}{l}\bullet \\
\bullet \\
\bullet \\
\bullet \\
\bullet\end{array}$ & $\begin{array}{l}\text { Fertilizer sacks } \\
\text { Agrochemical cans } \\
\text { Containers } \\
\text { Tanks for liquid storage } \\
\text { Crates }\end{array}$ \\
\hline PIPING, IRRIGATION /DRAINAGE & $\begin{array}{l}\bullet \\
\bullet \\
\bullet \\
\bullet \\
\bullet \\
\bullet\end{array}$ & $\begin{array}{l}\text { Water reservoir } \\
\text { Channel lining } \\
\text { Irrigation tapes and pipes } \\
\text { Drainage pipes } \\
\text { Micro-irrigation } \\
\text { Drippers }\end{array}$ \\
\hline OTHER USE & $\begin{array}{l}\bullet \\
\bullet \\
\bullet \\
\bullet \\
\bullet \\
\bullet\end{array}$ & $\begin{array}{l}\text { Silage films } \\
\text { Fumigation films } \\
\text { Bale twines } \\
\text { Bale wraps } \\
\text { Nursery pots } \\
\text { Strings and ropes }\end{array}$ \\
\hline
\end{tabular}

Source: SCARASCIA-MUGNOZZA, G., SICA, C., \& RUSSO, G. (2012). [15]

Among the most important uses of plastic materials in agriculture are their use for greenhouses, $47 \%$, for mulching $34 \%$ and for silages $19 \%$ (Fig. 1).

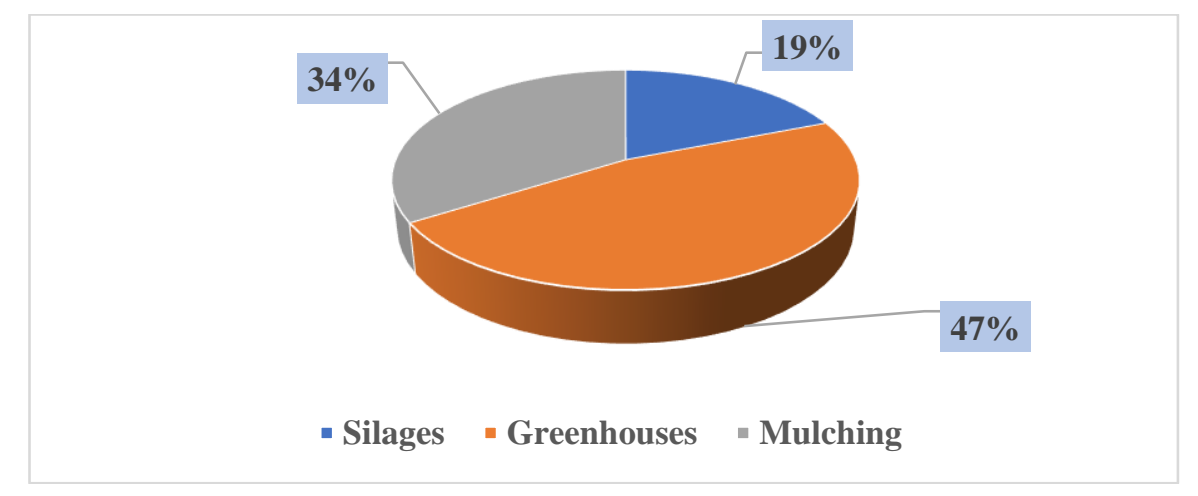

Fig.1. Share of the use of plasticulture 
Globally, plasticulture records the highest values in Asia and the trends are increasing for the next period, so at the level of 2018 was recorded the value of $4300 \mathrm{KT}$ and by 2030 it is estimated that the value of $7050 \mathrm{KT}$ will be reached, representing a growth of $64 \%$.

At the same time, at the level of Europe, even if plasticulture does not have such a high use compared to the Asian region, in 2018 the value was $650 \mathrm{KT}$ and the increase till 2030 will be of $105 \mathrm{KT}$, representing an increase of 51\% (Fig. 2).

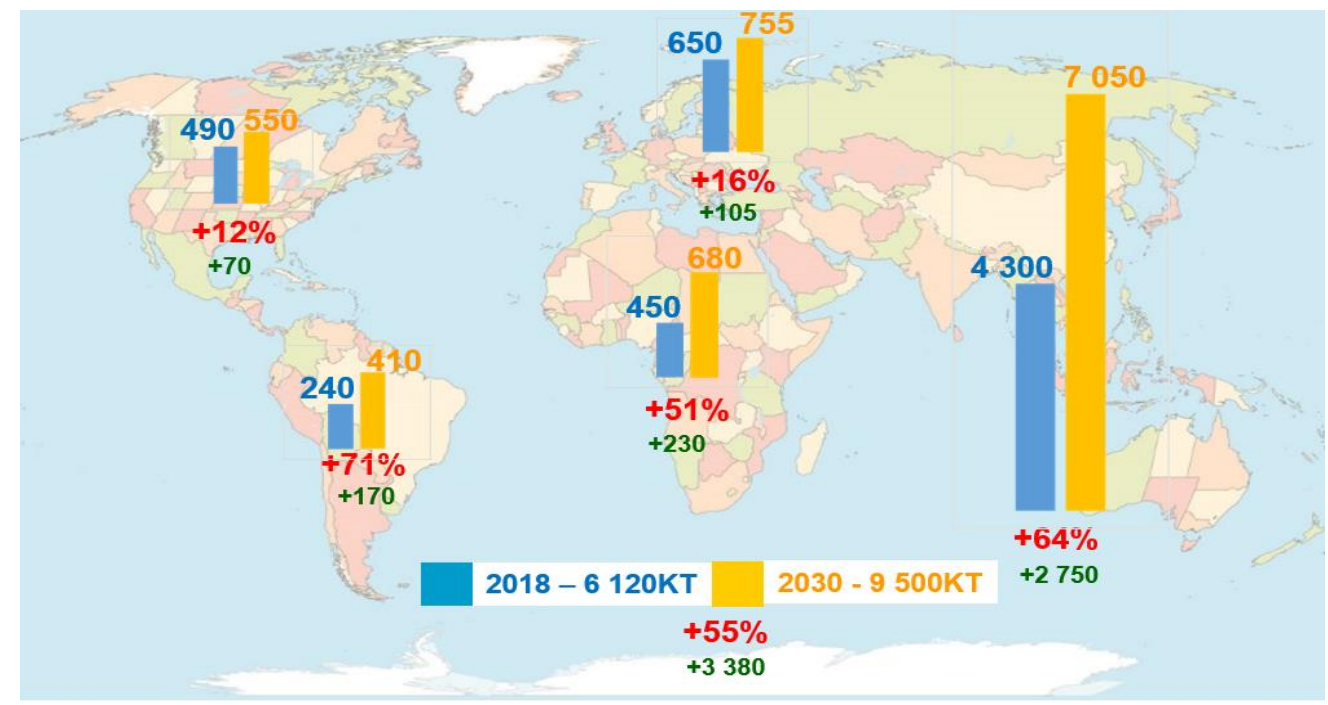

Source: CIPA Congress, Agriculture, plastics \& environment, XXI CIPA Congress, 2018

Fig. 2. Trends in plasticulture worldwide

The use of plastic materials can be multiple, but the advantages and disadvantages of plasticulture must be carefully analyzed, in detriment of the traditional practices.

Starting from the disadvantages, removing completely the mulching plastic foil from the soil is difficult to achieve and it decomposes very hard over time, having harmful effects on the soil.

However, plastics waste from agriculture is somewhere at 5\% at European level, but the highest values are made by packaging, meaning that is 12 times bigger and has a share of approx. 59\%.

Another disadvantage is the initial cost which is very high, requiring investments in machinery and equipment, but these costs are normally covered by increased yields and superior product quality. In addition to the above, more day-to-day management and monitoring is needed to succeed.

Regarding the advantages of using plastics, the mulching plastic foils are easy to install, durable and weather resistant. At the same time, it increase soil temperature and thus help plants grow, reaching maturity faster [9], providing a better yield.

At the same time, weeds are controlled because the light is not transmitted through the plastic film, so they are unable to grow. [21]

An example could be the spring crops grown on black mulching foil [2] which can be harvested up to three weeks earlier, this early harvest representing a major advantage on the market because the price received by the producer is much higher.

Since the goal of plastics is to improve production with fewer resources and to reduce costs implicitly so that can be done for the longest time, farmers must pay particular attention to the use of plastics and their recycling, in order to reduce negative effects. (Fig. 3) 


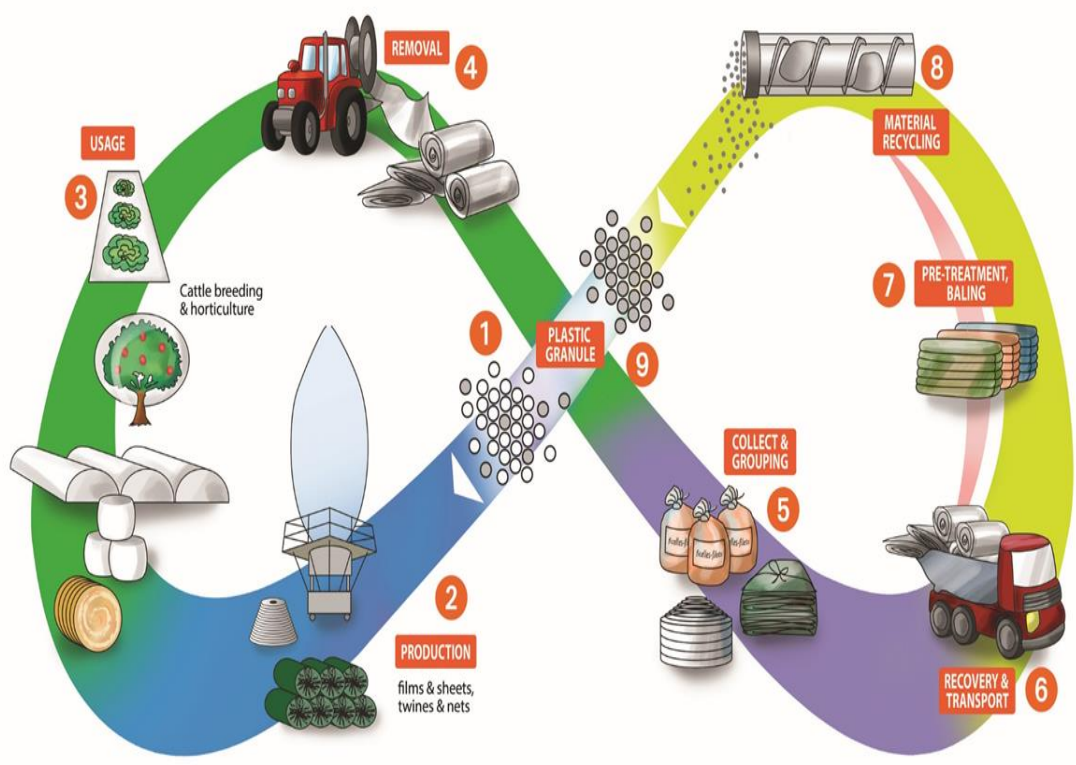

Source: CIPA Congress, Agriculture, plastics \& environment, XXI CIPA Congress, 2018. [3]

Fig. 3. The plasticultor's environmental responsibility

Unfortunately, due to the lack of a coherent policy of collecting plastic waste, bad practices such as burning [4] or burial remain today the main way of eliminating them as a result of the cessation of crops.

For helping the farmers, in Europe, as in many other regions of the world, public authorities are trying to reduce the amount of waste by developing a viable recycling system and limiting waste disposal or exports.

\section{Conclusions}

The plasticulture and the use of plastic materials in agriculture began to grow about 70 years ago when agronomists discovered that, by replacing on the glass they used for greenhouses with polyethylene and the straws and the paper used for mulching with plastic foil, they obtain earlier crops and higher yields, with fewer resources, therefore, at much lower costs. This is also the main advantage of the use of plastics in agriculture, as the need to provide food for the growing population, which is expected to be around $30 \%$ by 2050 , when the population will reach 10 billion people. Under these circumstances, food needs are estimated to have an increase between 50 and 60\%, because in addition to population growth, we also notice a change in their incomes, and thus increases pressure on food demand.

Given that, we can say that the use of plastics is the main solution for ensuring early production, feed for the growing population and for soil protection, reducing the quantities of pesticides, fertilizers and resources aimed at stimulating and developing crops, and, last but not least, the quality assurance of the productions.

Despite all these advantages, unfortunately, the intensive use of plastics also entails a risk of pollution, [5] as there are currently not too many alternatives to dispose waste, and practices such as burning or burial are still methods used by farmers.

Since plastics dependence is very large, more and more countries are trying to find solutions to support farmers and protect the soil, because in their absence about $75 \%$ of total production would be compromised without plasticulture.

\section{References}

1.BROWN, R., Polymers in Agriculture and Horticulture, iSmithers Rapra Publishing, 2004

2.CHALKER-SCOTT, L.,Impact of mulches on landscape plants and the environment-a review. J. Environ. Hortic. 25, 239,2007

3.CIPA Congress, Agriculture, plastics \& environment, XXI CIPA Congress, 2018.

4.CONSTANTINESCU, M., BUCURA, F., IONETE, R.E., NICULESCU, V.C., Comparative study on plastic materials as a new source of energyMat. Plast., 56, no. 1, p. 41-46, 2019.

5.DRAGOMIR BALANICA, C.M., SIMIONESCU, A.G., BIRSAN, I.G., BICHESCU, C.I., MUNTENITA, C., The assesment of using the sewage sludge in agriculture in Romania, Mat. Plast., 55, no. 4, p. 700-703, 2018

6.GARNAUD, J.C., Agricultural and Horticultural Applications of Polymers, Rapra Technology Ltd., Pergamon Press, Oxford, Shawbury, UK, 1988 7.GARNAUD, J.C., Plasticulture Magazine: A Milestone for a History of Progress in Plasticulture, Plasticulture, Vol. 119, p. 30-43, 2000

8.GODFRAY, H.C.J., BEDDINGTON, J.R., CRUTE, I.R., HADDAD, L., LAWRENCE, D., MUIR, J.F., PRETTY, J., ROBINSON, S., THOMAS, S.M., TOULMIN, C., Food security: the challenge of feeding 9 billion people. Science 327, 812-818, 2010

9.KASIRAJAN, S., NGOUAJIO,M., Polyethylene and biodegradablemulches for agricultural applications: a review. Agron. Sustain. Dev. 32, 501529., 2012 
10.LIU, E.K., HE, W.Q., YAN, C.R., "White revolution” to "white pollution" - agricultural plastic film mulch in China, Environmental Research Letters, vol. 9, No. 9, 2014

11.MCEWAN I., ARRIGHI V., COWIE J.M.G,Structure and properties of commonly recycled polymers, Handbook of Plastic Recycling, ed. Francesco La Mantia Rapra Technology, Shawbury, UK., 1-22, 2002

12.MOCUTA, D.N., CRISTEA, S., TUREK-RAHOVEANU, A., HOSSU, A.M., Applying risk management to mitigate the consequnces of climate change, Rev. Chim. (Bucharest), 69, no. 2, p.415-418, 2018.

13.MOCUTA, D.N., The influence of climate change on sustainable development, Economic and Social Development: Book of Proceedings, Varazdin Development and Entrepreneurship Agency (VADEA), pp. 316-321, 2018

14.PICUNO P., SCARASCIA-MUGNOZZA G., The management of agricultural plastic film wastes in Italy. Proceedings of the International Agricultural Engineering Conference, Bangkok (Thailand), p. 797-808, 1994

15.SCARASCIA MUGNOZZA, G., SICA, C., \& RUSSO, G. (2012). Plastic materials in european agriculture: actual use and perspectives., Journal of Agricultural Engineering, Vol. 42(3), p. 15-28.

16.SRINIDHI, A., NAZARETH, D., Use of plastic in agriculture is improving yield, but here's what else it's doing, YKA Environment, 2018.

17.TITA, V., MOCUTA, D.N., TUREK-RAHOVEANU, A., POPESCU, A.D., Bold, N., Integrated plastic management system within an agricultural enterprise, analysis of actual context, system model and simulation, Revista de materiale plastice, vol. 56., no. 2., p. 346-350, 2019.

18.TUDOR, V.C., MARIN, A., ZAMFIR VASCA, D., MICU, M.M., SMEDESCU, D.I., The influence of the plastic bags on the Environment, Materiale plastice, vol. 55, no.4, 2018.

19.VOX, G., LOISI, R.V., BLANCO, I., SCARASCIA MUGNOZZA, G., SCHETTINI, E., Mapping of agriculture plastic waste, Agriculture and Agricultural Science Procedia, 8, p. 583-591, 2016.

$20 . * * *$ https://www.plasticseurope.org/en/about-plastics/what-are-plastics

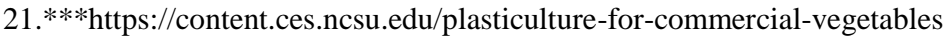

Manuscript received:27.07.2019 